\title{
EFFECT OF ORGANIC FERTILIZER AND BREAD WHEAT (Triticum aesitivum L.) GENOTYPES ON YIELD AND YIELD COMPONENTS
}

\author{
MuradJ an M.M. Noori ${ }^{*}$, Mohammed A. Hussain and AbBas Alo Khether ${ }^{* *}$ \\ *Dept. of Soil and Water sciences, College of Agricultural Engineering Sciences, University of Duhok, \\ Duhok, Kurdistan Region, Iraq \\ ** Dept. of Field Crops, College of Agricultural Engineering Sciences, University of Duhok, Duhok, \\ Kurdistan Region, Iraq.
}

(Received: October 13, 2020 ; Accepted for Publication: December 8, 2020)

\begin{abstract}
The experiment was carried out at College of Agricultural Engineering Sciences farm, Duhok University, the experiment was laid out in Randomize Complete Block Design with three replications and arranged in factorial experiment to evaluate the effect of organic fertilization levels and bread wheat genotypes (Tamoz-2, IPA-95 and Abu. Garib-3), and the foliar organic mineral fertilizer used at three rates $0.5,0.75$ and one litter.

The results showed highly significant effect of bread wheat genotypes in all studied characters with exception of weight grain spike ${ }^{-1}$, also organic fertilizer exhibited significant effect in plant height, leaf area, 1000-grain weight, number of grain spike, length of spike and grain yield, while the effect of interaction between genotypes and organic fertilizer levels showed highly significant effect for all characters except of spike length, the results indicated that the rate 1 liter and Abu. Garib-3 gave the maximum plant height, leaf area, 1000 grain weight, number of grain spike ${ }^{-1}$, weight of grain spike $\mathrm{e}^{-1}$, spike length and grain weight with values $(91.2,56.9,47.5,48.7,2.8,8.7$ and $355.0 \mathrm{gm})$ respectively.

The correlation coefficient of grain yields gave highly significant with plant height $(0.972)$, leaf area $(0.916), 1000$ grain weight $(0.923)$, number of grain spike ${ }^{-1}(0.951)$ and spike length $(0.974)$.

The results for this study had shown that, using organic fertilizer and suitable wheat genotypes effects significantly on yield and most of yield components.
\end{abstract}

KEY WORDS: Organic Fertilizer, Wheat, Genotype, Grain yield

\section{INTRODUCTION}

B read wheat is important dietary protein throughout the world, because it is a good source of protein and energy supply in most countries. (Gooding and Davies, 1998) and production, which is due to substandard methods of cultivation organic fertilizer defines, as all the additives with organic sources and this material provide the plant with its need of nutrients, Shand, (2007) source of these fertilizers are spontaneous and inexpensive in comparison with chemical fertilizer. crop in comparison with chemical fertilizer. Crop management factors such as the application of fertilizers have effect on yield, yield components and quality, what of the possible options to reduce the use of chemical fertilizer could be using of organic fertilizer, also using organic fertilizer may be supply plant with their need of nitrogen during growth by cheap means which in turn led to significant decrease in crop production cost. Many researchers using organic chemical fertilizer on different crops to increase grain yield quantity and quality. The continued use of chimerical fertilizers causes health and environmental hazards such as ground and surface water pollution by nitrate leaching (Tayebeh et al., 2010), so, reading the amount of nitrogen deficiency will be the main challenge in field management. One of the possible options of organic wastes, (Odlare et al., 2008). Al-Hilfy and Flayyah, (2018) found that the bread wheat genotypes response to mineral and organic fertilizers on yield and yield components.

The benefits of organic-organic fertilizer using to increasing grain yield of wheat are not always easy to optimize because the nitrogen content and its subsequent release being difficult to predict. Increasing grain yield of wheat by combined effect of organic-organic or organic and chemical fertilizer is more effect to increase 
grain yield wheat Nin et al., (2016). These benefits reported by Salih et al., (2018), all of them studied the effect of organic fertilizer on productivity of wheat and yield components, the results shown that, using organic fertilizer effects significant on dry weight of shoot, number of spikes $\mathrm{mm}^{2}$, number of seed spike ${ }^{-1}$, flag leaf area $\mathrm{cm}^{2}$, number of seed spike ${ }^{-1}$, plant height, number of tillers plant ${ }^{-1}$ and weight of seed spike ${ }^{-1}$. The present study aims to estimate the effect of organic fertilizer and wheat genotypes on yield and yield components.

\section{MATERIALS AND METHODS}

Field experiment was carried out on silty clay loam soil at the experimental farm of College of Agricultural Engineering Sciences, Duhok University. The experiment was laid out in Randomized Complete Block Deign (RCBD) with three replications and arranged in factorial experiment. The treatment included three levels of foliar organic mineral fertilizer (Super Armor $(6 \%$ Total N, 3\% Organic Nitrogen, and $3 \% \mathrm{~N}-\mathrm{NH}_{2}$ ) and used at three rate $0.5,0.75$ and one litter, as $(4.5,6.75$ and 9) $\mathrm{kg} \mathrm{ha}^{-1}$ these levels added as foliar application at tiller stage, before flowering and fulling seed stage, also NPK added after land preparation plowing (104, 156 and 208) $\mathrm{kg} \mathrm{ha}^{-1}$ as urea 46.N. The bread wheat genotypes (Tamoz-2, IPA-95 and Abu. Garib-3) were planted at 15/11/2018 at seeding rate of $180 \mathrm{~kg} \mathrm{ha}^{-1}$ in three rows. The physical and chemical analysis of the soil before implementation of the experiment is described in (Table 1).

Table (1): Some physical properties of the studied soil

\begin{tabular}{ccc}
\hline Soil property & Unit & $\begin{array}{c}\text { Depth } \\
\mathbf{( 0 - 3 0 )}\end{array}$ \\
\hline Sand & & 4.38 \\
\hline Silt & $\%$ & 45.21 \\
\cline { 3 - 3 } Clay & & 50.41 \\
\hline Soil texture & & Silty clay \\
\hline Bulk density & & 1.392 \\
\hline Om at $(-33)$ & $\mathrm{Mg} \mathrm{m}{ }^{-3}$ & 32.31 \\
\hline Om at $(-1500)$ & $\mathrm{kPa}$ & 20.16
\end{tabular}

The data on the individual plants (ten plants randomly selected from each experimental unit) were recorded on plant height, leaf area, 1000 grain weight, number of grain spike ${ }^{-1}$, weight of grain spike ${ }^{-1}$, spike length and $0.90 \mathrm{~m}^{2}$ grain yields. The data of each trait were analyzed according to experiment design method using Minitab 16.1.1 software. The comparison between mean of the treatments was made using Duncan's Multiple Range Test (DMRT)

\section{RESULTS AND DISCUSSION}

Analysis of variance for all characters for winter season 2018-2019 are presented in (Table 2 ), the results revealed that highly significant effects of bread wheat genotypes in all studied characters except of weight of grain spike ${ }^{-1}$, while the fertilizer application exhibited significant effect in plant height, leaf area, 1000grain weight, number of grain spike ${ }^{-1}$, spike length and grain yield. The interaction effect between genotypes and fertilizer application indicated highly significant effect for all characters with exception length of spike 
Table (2) Analysis variance of bread wheat characters under different levels of organic fertilizer, growing season 2018-2019.

\begin{tabular}{|c|c|c|c|c|c|c|c|c|}
\hline \multirow[t]{2}{*}{ Characters } & \multicolumn{2}{|c|}{ Blocks } & \multicolumn{2}{|c|}{ Genotypes } & \multicolumn{2}{|c|}{ Fertilizer Application } & \multicolumn{2}{|c|}{$\begin{array}{c}\text { Genotypes * Fertilizer } \\
\text { Interaction }\end{array}$} \\
\hline & $F 2,16$ & $\mathbf{P}$ & $F 2,16$ & $\mathbf{P}$ & $F 2,16$ & $\mathbf{P}$ & $\mathrm{F} 4,16$ & $\mathbf{P}$ \\
\hline $\begin{array}{l}\text { Plant Height } \\
\text { (cm) }\end{array}$ & 27.54 & $<0.0001$ & 4618.73 & $<0.0001$ & 610.6 & $<0.0001$ & 55.12 & $<0.0001$ \\
\hline $\begin{array}{l}\text { Leaf Area } \\
\left(\mathrm{cm}^{2}\right)\end{array}$ & 0 & 0.998 & 232.92 & $<0.0001$ & 45 & $<0.0001$ & 5.63 & 0.005 \\
\hline $\begin{array}{c}1000 \text { grain weight } \\
(\mathrm{g})\end{array}$ & 5.04 & 0.02 & 242.65 & $<0.0001$ & 28.85 & $<0.0001$ & 10.98 & $<0.0001$ \\
\hline No. of grains spike ${ }^{-1}$ & 12.6 & 0.001 & 1054.3 & $<0.0001$ & 135.1 & $<0.0001$ & 8.56 & 0.001 \\
\hline Wt. of grain spike ${ }^{-1}(\mathrm{~g})$ & 0.09 & 0.918 & 1.51 & 0.25 & 3.13 & 0.071 & 2.93 & 0.054 \\
\hline $\begin{array}{l}\text { Spike Length } \\
\text { (cm) }\end{array}$ & 2.78 & 0.092 & 736.23 & $<0.0001$ & 27.54 & $<0.0001$ & 0.58 & 0.682 \\
\hline Grain Yield Weight (g) & 0.41 & 0.673 & 1218.35 & $<0.0001$ & 74.92 & $<0.0001$ & 9.41 & $<0.0001$ \\
\hline
\end{tabular}

Generally statistical analysis showed that genotypes were significant effect in plant height, the tallest plant height related to Abu. Garib-3 $(86.6 \mathrm{~cm})$ followed by IPA-95 with value 75.1 $\mathrm{cm}$, (Table 3) this variation due to genetic difference of genotypes in the inter nodes length, this trait is one of the characteristic dominated by an additional gene. Results were similar to previous research (Kandil et al.,2010 and Amanullah et al.,2012). For the effect of genotypes, the results in same table exhibited significant effect in the flag leaf area, the maximum average belonged to Abu. Garib-3 $\left(54.0 \mathrm{~cm}^{2}\right)$, the difference in this trait refered to the difference in genotypes variation, these results in agreement with Amal and Zamri, 2011; Hussain et al., 2017 and Al-Alowy and Al.Bandawy, 2017. According to the results in (Table 3), the results indicated significant effect for genotypes in 1000-grain weight, Abu. Garib3 gave $44.0 \mathrm{~g}$ compare with other genotypes, from the same table, Abu. Garib-3 gave the largest value for leaf area, this trait makes a major contribution toward the grain weight and is the major photosynthetic site during the grain filling stage. Regarding too number of grain spike $^{-1}$, the results in (Table 3) revealed that the effect of genotypes were significant effect on grain number spike ${ }^{-1}$. The highest mean related to Abu. Garib-3 (45.8), this could explain by genetic variation in the number of spikelet in spike $^{-1}$, which determined by the fertile flowers on a spike. The findings are in agreement with Al-Hilfy and Flayyah, (2018). For spike length, the results clearly showed that the longest spike length $(8.5 \mathrm{~cm})$ found with Abu. Garib-3, while Tamoz-2 produced the shortest spike length (6.4 $\mathrm{cm})$, from this results also the length of spike, were more influenced by type of genotypes. Similar resulted by Al-Alowy and Al.Bandawy, 2017. From the results above Abu. Garib-3 variety gave the highest mean of the Plant Height, flags leaf area, 1000-grain weight, number of grain spike ${ }^{-1}$ and spike length. The values indicate that larger contribution of genotypes effect to the determination of grain yield these results go along with the results of Abedi et al., (2010) and Al-Hilfy and Flayyah, (2018). 
Table (3): Effect of bread wheat Genotypes on studied characters growing season 2018-2019

\begin{tabular}{cccccccc}
\hline Genotypes & $\begin{array}{c}\text { Plant Height } \\
(\mathrm{cm})\end{array}$ & $\begin{array}{c}\text { Leaf Area } \\
\left(\mathrm{cm}^{2}\right)\end{array}$ & $\begin{array}{c}1000 \\
\text { Grain } \\
\text { Weight }\end{array}$ & $\begin{array}{c}\text { No. of } \\
\text { Grain } \\
\text { Spike }\end{array}$ & $\begin{array}{c}\text { Wt. of grain } \\
\text { spike }\end{array}$ & $\begin{array}{c}\text { Spike } \\
\text { Length }(\mathrm{cm})\end{array}$ & $\begin{array}{c}\text { Grain Yield } \\
\text { Weight }(\mathrm{g})\end{array}$ \\
\hline Tamoz-2 & $67 \mathrm{c}$ & $33.7 \mathrm{c}$ & $33.5 \mathrm{c}$ & $33.1 \mathrm{c}$ & $1.4 \mathrm{a}$ & $6.4 \mathrm{c}$ & $177.2 \mathrm{c}$ \\
\hline IPA-95 & $75.1 \mathrm{~b}$ & $46.0 \mathrm{~b}$ & $38.3 \mathrm{~b}$ & $38.2 \mathrm{~b}$ & $1.8 \mathrm{a}$ & $7.4 \mathrm{~b}$ & $262.9 \mathrm{~b}$ \\
\hline $\begin{array}{c}\text { Abu. Garib- } \\
3\end{array}$ & $86.6 \mathrm{a}$ & $54.0 \mathrm{a}$ & $44.0 \mathrm{a}$ & $45.8 \mathrm{a}$ & $1.8 \mathrm{a}$ & $8.5 \mathrm{a}$ & $329.5 \mathrm{a}$ \\
\hline
\end{tabular}

Means with the same letter in each character are not significantly

Organic-fertilizer effect on bread wheat genotypes characters was presented in (Table 4), plant height was significant influenced by application of organic-fertilizer. The tallest of plant height was observed at the maximum rate $\left(1000 \mathrm{~cm}^{3}\right)$ of organic-fertilizer and recorded $79.6 \mathrm{~cm}$, whilst, shortest plant height was recorded in lower rate of $\left(250 \mathrm{~cm}^{2}\right)$ organicfertilizer. The application of organic-fertilizer plant height increased 9\% compare with lower rate of organic-fertilizer, De Ponti et al., (2012) reported similar results in bread wheat. Also Table (4) showed that the largest value for flag leaf area $\left(49.0 \mathrm{~cm}^{2}\right)$ produced by maximum rate of organic-fertilizer $\left(1000 \mathrm{~cm}^{3}\right)$, while the smallest leaf area $\left(40.0 \mathrm{~cm}^{2}\right)$ recorded by lower rate of organic-fertilizer

The results in the (Table 4) indicate that the organic-fertilizer effect on 1000-grain weight, maximum of this trait obtained under $1000 \mathrm{~cm}^{3}$ rate of organic-fertilizer (40.3 g), while the minimum value $(36.6 \mathrm{~g}$ ) was obtained by lower rate $\left(250 \mathrm{~cm}^{3}\right)$ and $9 \%$ increase than the lower rate, the results showed that, effect of organic- fertilizer on number of grain spike $^{-1}$, the maximum number of this trait obtained by 1000 $\mathrm{cm}^{3}$ of organic-fertilizer and recorded value 41.1, whilst the minimum value (36.6) exhibited by $250 \mathrm{~cm}^{3}$ of organic-fertilizer. For the spike length the longest value $(7.6 \mathrm{~cm})$ noticed by $1000 \mathrm{~cm}^{3}$ of organic-fertilizer and the shortest value showed in $250 \mathrm{~cm}^{3}$ of organic-fertilizer.

As shown in (Table 4), application of organic-fertilizer increased grain yield, the highest grain yield $(273.9 \mathrm{~g})$ recorded by 1000 $\mathrm{cm}^{3}$ of organic-fertilizer and the lowest value $(236.4 \mathrm{~g})$ exhibited by $250 \mathrm{~cm}^{2}$ of organicfertilizer more over the data in (Table 4), organic-fertilizer had significant effect on all yield components and some agronomic traits. Similar observation and conclusions were also reported by Zaki, (2016) and Hassanein et al., (2018). The results in (Table 4) indicating that the organic fertilizer with high level supply wheat crops with the in adequate nutrient, therefore, high yields recorded in addition of higher organic fertilizer application.

Table (4): Effect of Organic-Fertilizers levels on studied traits of bread wheat genotypes

\begin{tabular}{|c|c|c|c|c|c|c|c|c|}
\hline $\begin{array}{c}\text { Fertilizer } \\
\text { Level }\end{array}$ & Genotypes & $\begin{array}{l}\text { Plant } \\
\text { Height } \\
\text { (cm) }\end{array}$ & $\begin{array}{l}\text { Leaf } \\
\text { Area } \\
\left(\mathrm{cm}^{2}\right)\end{array}$ & $\begin{array}{c}1000 \\
\text { Grain } \\
\text { Weight }\end{array}$ & $\begin{array}{l}\text { No. of } \\
\text { Grain } \\
\text { Spike }^{-1}\end{array}$ & $\begin{array}{l}\text { Wt. of } \\
\text { grain } \\
\text { spike }^{-1} \\
\text { (g) }\end{array}$ & $\begin{array}{l}\text { Spike } \\
\text { Length } \\
\text { (cm) }\end{array}$ & $\begin{array}{l}\text { Grain Yield } \\
\text { Weight (g) }\end{array}$ \\
\hline $\mathrm{V}_{1}$ & Tamoz-2 & $72.4 \mathrm{c}$ & $40.0 \mathrm{c}$ & $36.6 \mathrm{~b}$ & $36.6 c$ & $1.5 a$ & $7.2 \mathrm{c}$ & $236.4 \mathrm{c}$ \\
\hline$V_{2}$ & IPA-95 & $76.6 b$ & $44.7 b$ & $38.8 a$ & $39.5 b$ & $1.5 \mathrm{a}$ & $7.4 b$ & $259.4 b$ \\
\hline$v_{3}$ & Abu. Garib-3 & $79.6 a$ & $49.0 a$ & $40.3 a$ & $41.1 a$ & $2 a$ & $7.6 a$ & $273.9 a$ \\
\hline
\end{tabular}

The effect of interaction between genotypes and organic-fertilizer on yield and yield components was presented in (Table 5), the results exhibited that the tallest plant height 91.2 $\mathrm{cm}$ were obtained by $\mathrm{V}_{3} \mathrm{~L}_{3}$ followed by $\mathrm{V}_{3} \mathrm{~L}_{2}$ which had $87.3 \mathrm{~cm}$. For leaf area, the interaction between organic-fertilizer and bread wheat genotypes, the treatment $\mathrm{V}_{3} \mathrm{~L}_{3}$ gave the largest value of flag leaf area $\left(59.9 \mathrm{~cm}^{2}\right)$, while the combination $\mathrm{V}_{1} \mathrm{~L}_{1}$ produced the minimum value $25.7 \mathrm{~cm}^{2}$, the increase in flag area was accompanied by increase in the frequency of 
organic-fertilizer, that could explain by the effect of organic-fertilizer in stimulating the growth regulators of plant, which led to an increase in the vegetative growth through elongating and division of cells that reflected and an increase in the flag area. From these results, they indicated a significant role of organic-fertilizer in increasing vegetative growth of wheat plant.

Concerning to 1000-grain weight, the results in (Table 5), showed the effect of genotypes, organic-fertilizer interaction between them on 1000 grain weight, the comparison of the mean value of this trait showed that Abu. Garib-3 variety with $1000 \mathrm{~cm}^{3}$ application of organicfertilizer had the highest (47.5 g) and variety with $250 \mathrm{~cm}^{2}$ application of organic-fertilizer had the longest ( $32.3 \mathrm{~g})$.

The effect of interaction between genotypes and organic-fertilizer on number of grain spike ${ }^{-1}$, Abu. Garib-3 variety with $1000 \mathrm{~cm}^{3}$ of organicfertilizer produce the maximum number of grain spike $^{-1}$ (48.7) and Tamoz-2 with $250 \mathrm{~cm}^{3}$ organic-fertilizer produced the minimum number of grain spike ${ }^{-1}$ with value (30.1).

Also the data in the same table revealed that the comparison of the mean values of weight of grain spike ${ }^{-1}$ showed that Abu. Garib-3 with the application $1000 \mathrm{~cm}^{3}$ of organic-fertilizer recorded the highest $(2.8 \mathrm{~g})$, whilst Tamoz- 2 with application $250 \mathrm{~cm}^{2}$ of organic-fertilizer had the longest weight $1.0 \mathrm{~g}$. for spike length the result in (Table 5) showed that Abu. Garib-3 variety with application $1000 \mathrm{~cm}^{3}$ organic-fertilizer had the longest length of spike $8.7 \mathrm{~cm}$, while Tamoz2 with application $250 \mathrm{~cm}^{3}$ obtained the minimum spike length $(6.2 \mathrm{~cm})$.

The effect of interaction between genotypes and organic-fertilizer, Abu. Garib-3 with application $1000 \mathrm{~cm}^{3}$ organic-fertilizer reported the maximum yield $355.0 \mathrm{~g}$ and Tamoz-2 variety with application $250 \mathrm{~cm}^{3}$ organic-fertilizer and had the minimum yield $169.8 \mathrm{~g}$. from the present study revealed that the effect of organic-fertilizer and wheat genotypes and interaction between them effected on all traits and the application of organic-fertilizer increase yield and its components of different genotypes of bread wheat genotypes. Similar results were found by Zaki, 2016; Hassanein et al., 2018 and AlNaqeeb et al., 2018. The high response of some varieties to organic fertilization, regardless, is mostly related to high organic fertilization and this quantity can supply wheat crops with enough nutrients which the plants needed.

Table (5): Effect of Bread Wheat Genotypes and Fertilizer level on studied traits

\begin{tabular}{cccccccc}
\hline $\begin{array}{c}\text { Treatments } \\
\text { Combination }\end{array}$ & $\begin{array}{c}\text { Plant Height } \\
(\mathrm{cm})\end{array}$ & $\begin{array}{c}\text { Leaf Area } \\
\left(\mathrm{cm}^{2}\right)\end{array}$ & $\begin{array}{c}1000 \\
\text { Grain } \\
\text { Weight }\end{array}$ & $\begin{array}{c}\text { No. of } \\
\text { Grain } \\
\text { Spike }^{-1}\end{array}$ & $\begin{array}{c}\text { Wt. of } \\
\text { grain } \\
\text { spike }\end{array}$ & $\begin{array}{c}\text { Spike } \\
\text { Length }(\mathrm{cm})\end{array}$ & $\begin{array}{c}\text { Grain Yield } \\
\text { Weight (g) }\end{array}$ \\
\hline V1L1 & $65.5 \mathrm{~g}$ & $25.7 \mathrm{f}$ & $32.3 \mathrm{~d}$ & $30.1 \mathrm{~g}$ & $1 . \mathrm{b}$ & $6.2 \mathrm{e}$ & $169.8 \mathrm{f}$ \\
\hline V1L2 & $67.0 \mathrm{fg}$ & $34.3 \mathrm{e}$ & $33.8 \mathrm{~d}$ & $34.3 \mathrm{f}$ & $1.3 \mathrm{~b}$ & $6.3 \mathrm{e}$ & $179.1 \mathrm{f}$ \\
\hline V1L3 & $68.5 \mathrm{ef}$ & $41 \mathrm{~d}$ & $34.2 \mathrm{~cd}$ & $34.9 \mathrm{ef}$ & $1.4 \mathrm{ab}$ & $6.5 \mathrm{e}$ & $182.7 \mathrm{f}$ \\
\hline V2L1 & $70.7 \mathrm{e}$ & $43 \mathrm{~d}$ & $37.7 \mathrm{bc}$ & $36.9 \mathrm{de}$ & $1.4 \mathrm{ab}$ & $7.1 \mathrm{~d}$ & $233.4 \mathrm{e}$ \\
\hline V2L2 & $75.5 \mathrm{~d}$ & $45.8 \mathrm{~cd}$ & $38.0 \mathrm{~b}$ & $38.0 \mathrm{~cd}$ & $1.5 \mathrm{ab}$ & $7.4 \mathrm{~cd}$ & $271.4 \mathrm{~d}$ \\
\hline V2L3 & $79.0 \mathrm{c}$ & $49.1 \mathrm{bc}$ & $39.0 \mathrm{~b}$ & $39.8 \mathrm{c}$ & $1.7 \mathrm{ab}$ & $7.6 \mathrm{c}$ & $284.0 \mathrm{~d}$ \\
\hline V3L1 & $81.2 \mathrm{c}$ & $51.3 \mathrm{~b}$ & $39.7 \mathrm{~b}$ & $42.7 \mathrm{~b}$ & $1.8 \mathrm{ab}$ & $8.3 \mathrm{~b}$ & $305.9 \mathrm{c}$ \\
\hline V3L2 & $87.3 \mathrm{~b}$ & $53.9 \mathrm{ab}$ & $44.9 \mathrm{a}$ & $46.2 \mathrm{a}$ & $1.9 \mathrm{ab}$ & $8.6 \mathrm{ab}$ & $327.5 \mathrm{~b}$ \\
\hline V3L3 & $91.2 \mathrm{a}$ & $56.9 \mathrm{a}$ & $47.5 \mathrm{a}$ & $48.7 \mathrm{a}$ & $2.8 \mathrm{a}$ & $8.7 \mathrm{a}$ & $355.0 \mathrm{a}$ \\
\hline Means & & & & &
\end{tabular}

Means with each column which got the same letter are not significantly

\section{A Correlation Among Characters}

Data in (Table 6) showed the correlation among all pairs of traits. Highly significant and positive correlation $(0.907)$ was noticed between leaf area and plant height, while 1000-grain weight positive gave highly significant correlation with plant height and leaf area and the value were 0.938 and 0.868 respectively, also positive and highly significant correlated between number of grain spike ${ }^{-1}$ with plant height $(0.963)$, leaf area $(0.925)$ and $(0.971)$ for 1000-grain weight. Length of spike has highly significant positive correlation $(0.975,0.924$, 0.915 and 0.954) with plant height, leaf area, 1000-grain weight, and number grain spike ${ }^{-1}$, respectively and non-significant with weight of 
grain spike ${ }^{-1}$. Concerning grain yield plant $^{-1}$, highly significant and positive correlation $(0.972,0.916,0.923,0.951$ and 0.974$)$ with plant height, leaf area, 1000-grain weight, number of grain spike ${ }^{-1}$, and length of spike, respectively and non-significant with weight grain spike ${ }^{-1}$. From the results above showed that two agronomic traits were positively correlated with grain yield plant ${ }^{-1}$ and three characters of yield components correlated with grain yield. Correlations are very important in plant breeding because of its reflection independence between studied characters to determine the program using to improve the bread wheat genotypes. Similar finding was obtained by Jee et al., (2019).

Table (6): Simple Correlation Coefficient Between Among Studied Characters

\begin{tabular}{cccccccc}
\hline & $\begin{array}{c}\text { Plant } \\
\text { Height } \\
\mathrm{cm}\end{array}$ & $\begin{array}{c}\text { Leaf } \\
\text { Area } \\
\mathrm{cm}^{2}\end{array}$ & $\begin{array}{c}\text { Wt. of } 1000 \\
\text { grain } \\
(\mathrm{g})\end{array}$ & $\begin{array}{c}\text { No. of grain } \\
\text { spike }^{-1}\end{array}$ & $\begin{array}{c}\text { Wt. of grain } \\
\text { spike }^{-1}(\mathrm{~g})\end{array}$ & $\begin{array}{c}\text { Ave. Length } \\
\text { of Spike } \\
\mathrm{cm}\end{array}$ & $\begin{array}{c}\text { Wt. of } \\
\text { Production (g) }\end{array}$ \\
\hline $\begin{array}{c}\text { Leaf Area } \\
\mathrm{cm}^{2}\end{array}$ & $0.907^{\star *}$ & & & & & &
\end{tabular}

Wt. of 1000 grain $(\mathrm{g}) \quad 0.938^{\star \star} \quad 0.868^{\star \star}$

\begin{tabular}{ccccc}
\hline No. of grain spike ${ }^{-1}$ & $0.963^{\star \star}$ & $0.925^{\star \star}$ & $0.971^{\star \star}$ & \\
& & & & \\
\hline Wt. of grain spike & & \\
& & & & \\
\hline & 0.003 & -0.342 & -0.016 & -0.085
\end{tabular}

\begin{tabular}{|c|c|c|c|c|c|}
\hline Ave. Length of Spike cm & $0.975^{\star \star}$ & $0.924^{\star \star}$ & $0.915^{\star \star}$ & $0.954^{\star *}$ & -0.021 \\
\hline
\end{tabular}

\begin{tabular}{|c|c|c|c|c|c|c|}
\hline Wt. of Production (g) & $0.972^{\star \star}$ & $0.916^{\star *}$ & $0.923^{* *}$ & $0.951^{\star *}$ & -0.014 & $0.974^{\star *}$ \\
\hline \multicolumn{7}{|c|}{ ** Correlation significant at $\mathrm{p}$ value less than 0.01} \\
\hline \multicolumn{7}{|c|}{ * Correlation significant at $\mathrm{p}$ value less than 0.05} \\
\hline
\end{tabular}

\section{REFERENCE}

Abedi, T., Alemzadeh, A. and Kazemeini, S.A., 2010. Effect of organic and inorganic fertilizers on grain yield and protein banding pattern of wheat. Australian Journal of Crop Science, 4(6), P:384.

Al-Alowy H.H. and B.R-Al.Bandawy.2017 Effect of organic fertilizer and nitrogen on growth of wheat growing in salt soil Al-Qadisiya.J. Agr. Sci.(V) 1. P:136-142.

Al-Hilfy. H. and M. Flayyah, 2018. Response of two wheat genotypes yield to mineral, Organic-and organic fertilizers Iraqi Journal of Agri. Sci. Vol (48) 6. P: 1661-1671.

Al-Naqeeb, M.A.R., Al-Hilfy, I.H.H., Hamza, J.H., Al-Zubade, A.S.M. and Al-Abodi, H.M.K., 2018. Organic fertilizer (EM-1) effect on

muradjan.mudhaffar@uod.ac 
growth and yield of three bread wheat cultivars. Journal of Central European Agriculture, 19(3), P: 530-543.

Amal, M.N.A. and Zamri-Saad, M., 2011. Streptococcus's in tilapia (Oreochromis niloticus): a review. Pertanika Journal of Tropical Agricultural Science, 34(2), P: 195206.

Amanullah, Asif, M., Almas, L.K., Jan, A., Shah, Z., Rahman, H.U. and Khalil, S.K., 2012. Agronomic efficiency and profitability of Pfertilizers applied at different planting densities of maize in Northwest Pakistan. Journal of plant nutrition, 35(3), P: 331-341.

De Ponti, T., Rijk, B. and Van Ittersum, M.K., 2012. The crop yield gap between organic and conventional agriculture. Agricultural systems, 108, P:1-9.

Gooding, M. J. and W.P.Davies.1998. Wheat production and utilization systems, quality and environment Royal. Agr. college Cirehcester. UK Combridge. P: 147-165.

Hassanein, M.S., Ahmed, A.G. and Zaki, N.M., 2018. Effect of nitrogen fertilizer and organicfertilizer on yield and yield components of two wheat cultivars under sandy soil. Middle East J. Appl. Sci, 8(1), P: 37-42.

Hussain, M.A., Dohuki, M.S.S. and Ameen, H.A., 2017. Response of some bread wheat (Triticum aesitivum L.) cultivars to nitrogen levels. Kufa Journal for Agricultural Sciences, 9(4), P: 365-390.

Jee, C., Pathak, V.N., Verma, S.P., Verma, O.P. and Singh, O.P., 2019. Association studies for grain yield and its contributing components in diverse genotypes of wheat (Triticum aesitivum L. em. Thell). Journal of
Pharmacognosy and Phytochemistry, 8(3), P: 1177-1180.

Kandil, A.A., El-Kalla, S.E., Badawi, A.T. and ElShayb, O.M., 2010. Effect of hill spacing, nitrogen levels and harvest date on rice productivity and grain quality. Crop Environ, 1(1), P: 22-26.

Nin, Y., Diao, P., Wang, Q., Zhang, Q., Zhao, Z. and Li, Z., 2016. On-Farm-Produced Organic Amendments on Maintaining and Enhancing Soil Fertility and Nitrogen Availability in Organic or Low Input Agriculture. ORGANIC FERTILIZERS, p.289.

Odlare. M,M. pell and K.svensson. 2008. Change in soil chemical and micro-organic-logical properties during 4 years of application of various organic residues Waste Mangae.28 P: 1246-1253.

Salih .H. F. Al, M. Maysoun, and Nabeel K. At kaeth and Al.Reem. 2018.Respose of wheat IPA 99 (Triticum aesitivum L) to different types of organic fertilizer, Journal of Al-Muthanna for agric. Sci.(6)3: P:75=81.

Tayebeh. A; A. Abass and A. K. Seyed 2010. Effect of organic and inorganic fertilizers on grain yield and protein handing pattern of wheat. Australian Journal of crop science 4 (6) P: 334-389.

Zaki, S.S., 2016. Effect of compost and nitrogen fertilization on yield and nutrients uptake of rice crop under saline soil. Modern Chemistry and Applications, 4, P:183.

Shand, C., 2007. Plant Nutrition for Food Security. A Guide for Integrated Nutrient Management. By RN Roy, A. Finck, GJ Blair and HLS Tandon. Rome: Food and Agriculture Organization of the United Nations (2006), pp. 348, US \$70.00. ISBN 92-5-105490-8. Experimental Agriculture, 43(1), P:132-132. 


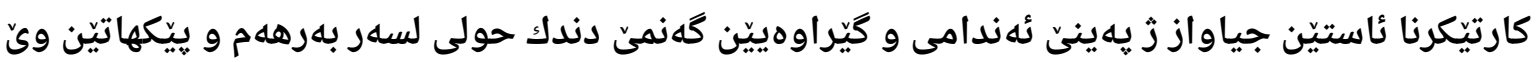

يوخته

ئهث فهوكولينه ل زهفى يا كوليزًا زانستيّن ئهندازيارييا ٍاندنى/ زانكويا دهوك هاتيه ئهنجامدان،

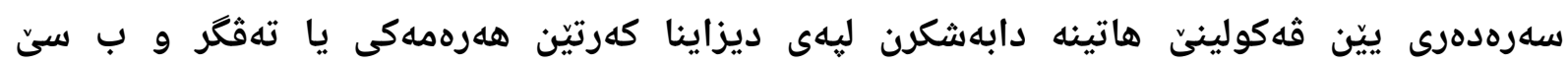

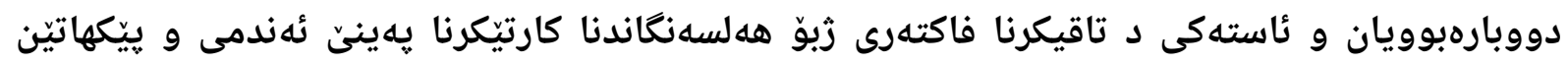

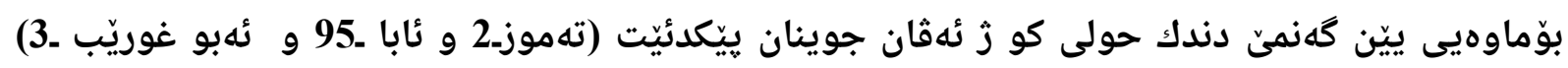

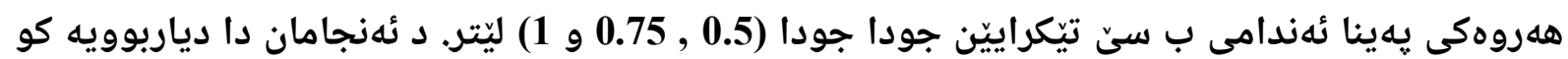

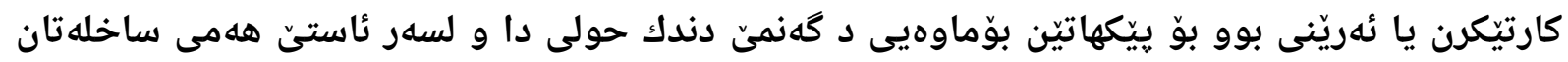

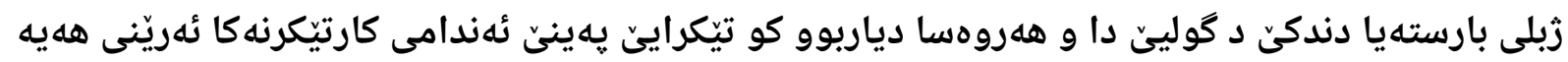

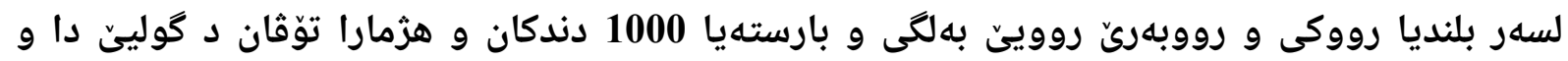

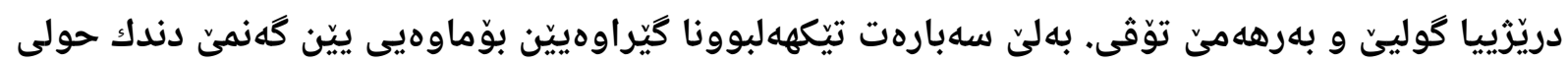

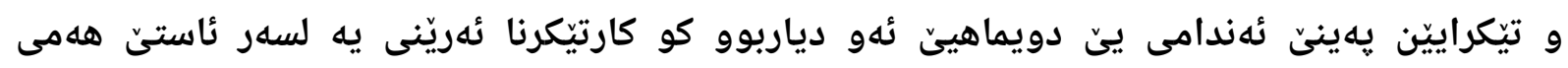

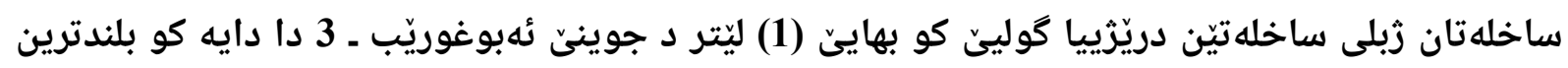

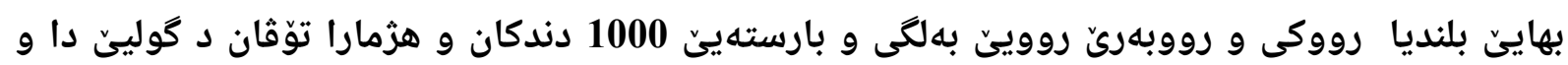

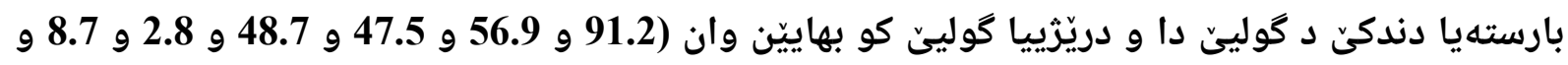

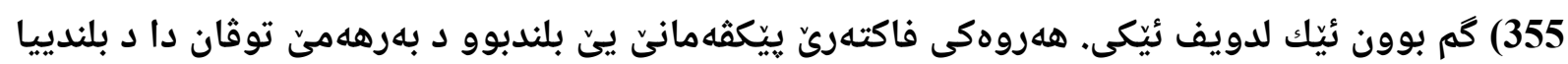

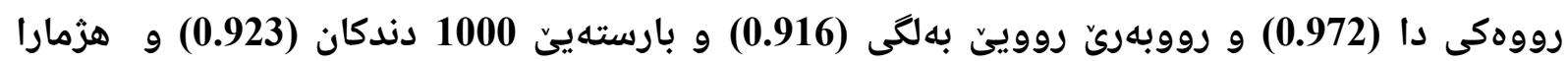

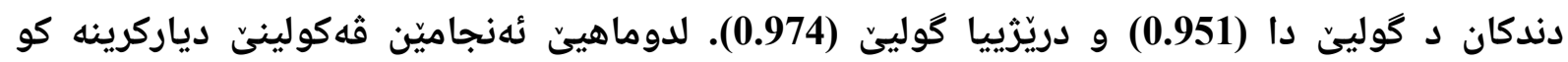

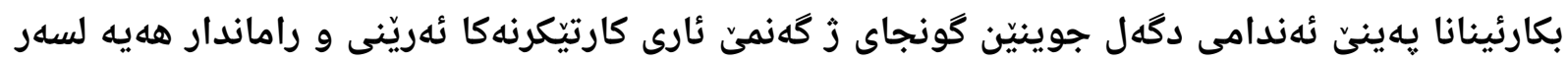

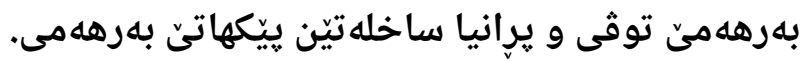
شوكه بهيف: يهينى ئهندامى، گهنم، جوينيّن، بهرهه مى دندكان. 
تأثير مستويات مختلفة من السماد العضوي و تراكيب من الحنطة الناعمة على الحاصل و مكوناته

الخلاصة

أجريت هذه الدراسة في حقل كلية علوم الهندسة الزراعية/جامعة دهوك و قسمت المعاملات وفق تصميم القطاعات العشوائية الكاملة و بثلاث مكررات ومرتبة في تجربة عاملية لتقييم تأثير السماد

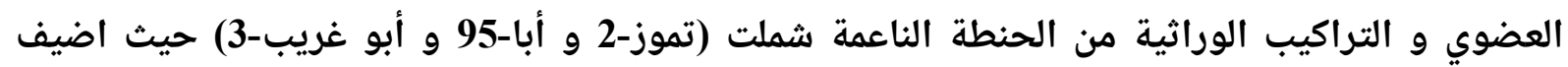

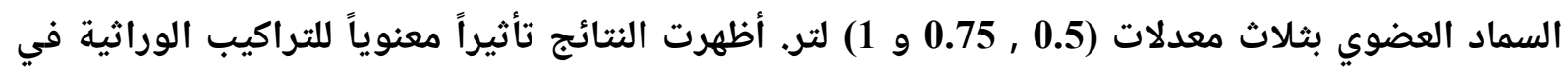

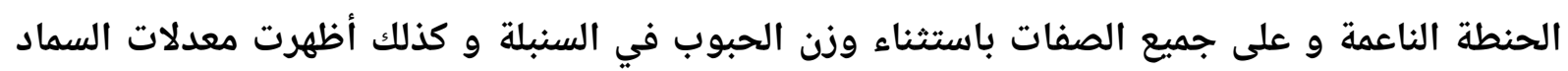

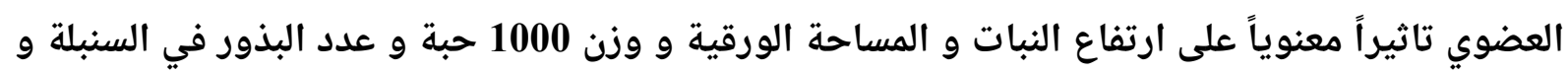
طول السنبلة و حاصل البذور. أما بالنسبة الى التداخل بين التراكيب الوراثية في الحنطة و معدلاتلات السماد العضوي هي الأخرى أظهرت تاثيراً معنويا على جميع الصفات باستثناء صفة طول السنبلة و اعطى المعدل (1) لتر مع الصنف أبو غريب-3 اعلى القيم لارتفاع النبات و المساحة الورقية و وزن 1000 حبة و عدد البذور في السنبلة و وزن وند

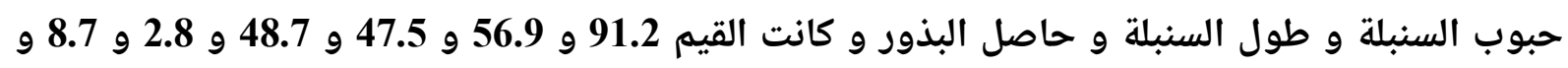
355 غرام على التوالي. كما كان معامل الارتباط عالي المعنوية في حاصل البذور مع ارتفاع النبات (0.972) و المساحة الورقية (0.916) و وزن 1000 بذرة (0.923) و عدد البذور في السنبلة (0.951) و طول السنبلة (0.974). أظهرت نتائج الدراسة ان استعمال السماد العضوي مع الصنف الملائم من حنطة الخبز له تأثير معند معنوي على حاصل البذور و معظم صفات مكونات الحاصل. الكلمات المفتاحية: السماد العضوي , الحنظة , أصناف , حاصل الحبوب 